\title{
An Analysis of Constraints Faced by the Tribes in the Adoption of Recommended Rangini Lac (Kerria Lacca) Production Technology in Chhattisgarh State
}

\author{
Harishchandra Tanwar ${ }^{1 *}$, P.K. Pandey ${ }^{1}$ and Ashish Kumar Gupta ${ }^{2}$ \\ 1Department of Agricultural Extension, IGKV, Raipur, Chhattisgarh, India \\ ${ }^{2}$ NICE System, NABARD-KfW Soil Project, MANAGE, Hyderabad, Telangana, India \\ *Corresponding author
}

The objective of this study was to identify the constraints encountered by the tribes in Rangini lac (Kerria lacca) production in Chhattisgarh state. To serve this purpose total 120

\section{Keywords}

Constraints, Tribes Rangini Lac (Kerria Lacca), Socio personal constraints

Article Info

\section{Accepted:}

12 December 2020

Available Online:

10 January 2021 respondents were taken from 2 blocks of Korba district in the year 2018-19. The pre structured interview schedule was used for the data collection. On the basis of findings constraints faced by the tribes in rangini lac (Kerria lacca) production divided into 4 categories viz., socio personal, technical, institutional and other constraints. Under socio personal constraints, maximum severity (87.22\%) was found for 'lack of knowledge regarding suitable plant part for inoculation in host tree' and with regards to technical constraints, maximum severity $(91.11 \%)$ was recorded for 'viral infection in brood lac'. Similarly, for institutional constraints, the highest severity $(88.61 \%)$ was observed in case of 'lack of crop insurance policy for Rangini lac production'. While the other constraints face by the respondents were 'non availability of labour at proper time' and 'non availability of instruments for harvesting' with severity percentage 77.77 percent and 93.33 percent, respectively. The major suggestions given by Rangini lac producers to overcome the constraints faced by them were as follows, 'extension agency should organize training and skill demonstration about different aspects of lac production technology at village level' and 'insurance of the lac crop should be provided by Govt.

\section{Introduction}

Lac is a natural heritage of our country has been associated with tribal and poor people providing regular income in absence of other cash crops. Two strains of Kerria lacca i.e. Rangini and kusmi contribute significantly in lac production. About 85 per cent of the country's production is exported to various countries. Due to its wide variety of applications in industries and in various uses the demand for lac is increasing day by day. So there is a need of promoting lac cultivation. Chhattisgarh has immense potential in terms of favourable climate, soil type, geography and natural conditions. 


\section{Materials and Methods}

The study was conducted in Korba district of Chhattisgarh state during 2018-19. Chhattisgarh state is divided into 27 district i,e., Sarguja, Balrampur, Surajpur, Koria, Bilaspur, Mungeli, Korba, Jashpur, Kabirdham, Durg, Balod, Bemetara, Raipur, Balodabazar, Gariyaband, Janjgir-Champa, Raigarh, Rajnadgoan, Dhamtari, Mahasamund, Kanker, Bastar, Kondagaon, Sukma, Dantewada, Narayanpur and Bijapur. Out of these, Korba district was selected purposively because this district having maximum forest area and cultivation of Rangini lac in the state. Korba district has 5 blocks namely Korba, Kartala, Katghora, Pondi-Uprora and Pali.

Out of these 5 blocks, only two blocks namely Korba and Pondi-Uprora will be selected purposively for the study. Four representative villages from each of the selected block will be selected randomly among the lac growing villages of the respective block. In this way, total 8 villages will be considered for this study. 15 Rangini lac producers were selected randomly from each of the selected randomly from each of the selected village. In this way, a total of 120 Rangini lac producers were considered as respondents for study purpose. The data was collected personally by using structured interview schedule and appropriate statistical tools will be used for the computation and analysis of research data.

\section{Results and Discussion}

\section{Socio personal constraints}

Various constraints related to social and personal issues of the respondents in study area was discussed under this category. In case of higher level of constraints, majority of the respondents $(68.33 \%)$ were reported that they have not sufficient knowledge regarding suitable plants part for inoculation of lac broods in host tree which is major constraints and reported as higher level of constraints which was followed by 63.33 and 37.50 percent respondents who reported that lack of knowledge regarding selection of healthy and suitable host plant and lack of knowledge of favorable time for inoculation of lac brood in host plant as higher level of constraints respectively. While, 19.17 percent respondents were felt that, their low level of education is major hindrance towards adoption of recommended lac production technology. There were also few proportion of respondents $(13.33 \%)$ who said that, there is lack of interest towards lac cultivation which results in non adoption of the packages of practices of lac production technology. This is due to endorsement of forest department, who delivers the lac seeds to the farmers for lac cultivation to just complete their physical target as given by forest department.

In case of medium level of constraints as reported by the respondents, majority of the respondents $(29.17 \%)$ were reported lack of knowledge of favorable time of inoculation followed by 27.84 percent respondents perceived lack of knowledge of suitable plant for inoculation of lac brood. While, 15.83 percent respondents reported low level of education as medium level of constraints towards technology adoption.

Majority of the respondents (68.34 and $55.84 \%$ ) were perceived that lack of interest and low level of education is not a constraint for adoption of packages of practices of Rangini lac production respectively.

The maximum high severity percent in socio personal constraints is Lack of knowledge regarding suitable plant part for inoculation in host tree 87.22 percent and minimum severity percent is Low level of education 14.16 percent. 


\section{Technological constraints}

Various technical constraints were also reported by respondents towards adoption of recommended Rangini lac cultivation technology. In case of higher level of the technical constraints, severe attack of red ant, mortality of brood lac, untimely harvesting of crop, poor quality of inoculate, viral infection in brood lac as higher level of constraints towards production of Rangini lac which were reported by $80.83,72.50,63.33,55.00$ and 48.33 percent respondents respectively. Whereas, 23.33 percent respondents were faced the problem to use efficiently the instruments used for Rangini lac production which was a major hurdle for them. Only 4.17 percent respondents reported non-availability of inoculate at proper time as higher level of constraints in lac production. In case of medium level of technological constraints, majority of the respondents (28.33\%) were reported the poor quality inoculate as a problem with medium level of severity in lac cultivation followed by 21.67 percent respondent who reported viral infection of brood lac is also a medium level of constraint in lac production technology. Mortality of brood lac and untimely harvesting of crop were also reported as medium level of constraints by the 18.33 and 17.50 percent of the respondents respectively. Whereas, non availability of inoculates and unable to use the instruments were also reported as medium level of constraint by 11.67 and 10.00 percent respondents respectively. Only 9.16 percent respondents were perceived that the severe attack of red ant is medium level of constraints in production of Rangini lac. Various technical issues were also perceived as lower level of constraint by the respondents in lac production was untimely harvesting crop $(10.83 \%)$ followed by poor quality of inoculate and viral infection in brood lac $(10.00 \%)$ while, mortality of brood lac and non-availability of inoculate were also reported as low level constraint by 7.50 and 6.66 percent respondents. About 5.84 percent respondents were considered lower level constraints to the severe attack of the red ants during the premature stage of lac crop. About 77.50 percent respondents were perceived that the non-availability of the inoculate is not a constraints in lac production followed by 62.50 percent respondents who were also not considered the unability to use the instruments in lac cultivation as the constraint. About 20.00 percent respondents were also put the viral infection in brood lac as nil constraint category.

The maximum high severity percent in technical constraints is Untimely harvesting of crop percent and minimum severity percent is 88.88 percent and Mortality of brood lac 15.00 percent.

\section{Institutional constraints}

Various institutional constraints were also faced by the respondents which were placed in higher, medium, low level of constraints categories. Majority of the respondents $(85.84 \%)$ were reported that lack of insurance policy for lac cultivation is serious problem in lac production followed by 83.83 percent respondents who stated problem of middleman in marketing channel is also a very high level of constraint for the lac producers. Lack of credit facility and lack of processing unit of produce at nearby place was perceived by 72.50 and 64.17 percent respondents as the higher level of constraint towards Rangini lac production. While, 45.84 percent respondents were also reported the lack of institutional support as major hindrance in lac production. Above constraints were also perceived as medium level of constraint by some of the respondents during the course investigation. About 41.67 percent respondents stated lack of institutional support as medium level of constraint 
followed by 16.66 percent respondents who perceived the lack as of processing unit of produce at nearby place as medium level of constraint. About 9.17 percent lac producers reported problem of middleman and lack of insurance policy for lac cultivation as the medium category of constraint. Only 5.53 percent respondents perceived the lack of credit facility as the medium level constraints in Rangini lac cultivation.

In case of lower level of constraints, majority of the respondents (11.66\%) were reported lack of institutional support as less problematic followed by 7.70 percent lac growers who reported lack of processing unit of produce at nearby place as low level constraint. About 5.00 percent respondents reported problem of middleman in marketing channel followed by 4.17 and 4.16 percent respondents who reported lack of credit facility and insurance policy for lac cultivation as lower level of constraint. Some of the respondents were also there who were not perceived above issues as constraints in way of Rangini lac production in the study area. About 17.50 percent of the respondents have stated that the lack of credit facility is not any constraint in lac production followed by 8.33 percent respondents who were not considered the lack of processing unit of lac at nearby place. About 5.00 percent respondents were also not blamed the middleman as the problem during the marketing of produce.

The maximum high severity percent in institutional constraints Lack of crop insurance policy for Rangini lac production 88.61 percent and minimum severity percent is Lack of institute for training center 21.38 percent.

\section{Other constraints}

Non-availability of instruments during the harvesting of lac crop has reported by 85.83 percent respondents very severe level of constraints followed by 20.00 percent of the respondents who reported non-availability of labours at proper time as low level of constraints. While, about 69.17 percent respondents were not considered the non availability of labour at proper time as constraint towards production of Rangini lac.

The maximum high severity percent in other constraints Non availability of instruments for harvesting 93.33 percent and minimum severity percent is Non availability of labour at proper time 77.77 percent.

\section{Suggestions}

As referred to Table: 6 suggestions given by lac growers for reduce the constraints faced by them during the adoption of recommended Rangini lac production technology.

Majority of the respondents (98.33\%) suggested that the extension agency should organize training and skill demonstration about different aspects of lac production technology at village level followed by respondents $(97.50 \%)$ who stated that the insurance of the lac crop should be provided by Govt.

The other important suggestion given by them are as follows, Quality seed of lac should be available (95.83\%), incentives should be given by Govt. to lac producers $(95.00 \%)$ and small processing unit should be established by Govt. (90.00\%). Whereas 45.83 percent respondents suggested for better market facility at nearby place for hassel free marketing of lac.

About 32.00 percent respondents were suggested about the availability of insecticides and fungicides should be at proper time for the protection of lac from harmful insect and disease. 
Table.1 Distribution of the respondents according to socio personal constraints faced by them

\begin{tabular}{|c|c|c|c|c|c|c|}
\hline \multirow[t]{2}{*}{ S.N } & \multirow[t]{2}{*}{ Constraints } & High & Medium & Low & Nil & \multirow{2}{*}{$\begin{array}{c}\text { Severity of } \\
\text { constraints } \\
\%\end{array}$} \\
\hline & & F/\% & F/\% & F/\% & F/\% & \\
\hline 1. & $\begin{array}{l}\text { Lack of knowledge regarding suitable plant } \\
\text { part for inoculation in host tree }\end{array}$ & $\begin{array}{c}82 \\
(68.33)\end{array}$ & $\begin{array}{c}31 \\
(27.84)\end{array}$ & $\begin{array}{c}6 \\
(5.00)\end{array}$ & $\begin{array}{c}01 \\
(0.83)\end{array}$ & 87.22 \\
\hline 2. & $\begin{array}{l}\text { Lack of knowledge selection of host plant } \\
\text { for better inoculation }\end{array}$ & $\begin{array}{c}76 \\
(63.33)\end{array}$ & $\begin{array}{c}24 \\
(20.00)\end{array}$ & $\begin{array}{c}12 \\
(10.00)\end{array}$ & $\begin{array}{c}8 \\
(6.67)\end{array}$ & 80.00 \\
\hline 3. & $\begin{array}{l}\text { Lack of knowledge regarding favorable } \\
\text { time for inoculation and lack of instruments }\end{array}$ & $\begin{array}{c}45 \\
(37.50)\end{array}$ & $\begin{array}{c}35 \\
(29.17)\end{array}$ & $\begin{array}{c}30 \\
(25.00)\end{array}$ & $\begin{array}{c}10 \\
(8.33)\end{array}$ & 65.27 \\
\hline 4. & Lack of interest in Rangini lac cultivation & $\begin{array}{c}16 \\
(13.33)\end{array}$ & $\begin{array}{c}7 \\
(5.83)\end{array}$ & $\begin{array}{c}15 \\
(12.50)\end{array}$ & $\begin{array}{c}82 \\
(68.34)\end{array}$ & 31.38 \\
\hline 5. & Low level of education & $\begin{array}{c}23 \\
(19.17)\end{array}$ & $\begin{array}{c}19 \\
(15.83)\end{array}$ & $\begin{array}{c}11 \\
(9.16)\end{array}$ & $\begin{array}{c}67 \\
(55.84)\end{array}$ & 14.16 \\
\hline
\end{tabular}

$\mathrm{F}^{*}=$ Frequency; $\quad \%=$ Percentage

Table.2 Distribution of the respondents according to technical constraints faced by the Rangini lac producers

$(n=120)$

\begin{tabular}{|c|c|c|c|c|c|c|}
\hline \multirow[t]{2}{*}{ S.N. } & \multirow[t]{2}{*}{ Constraints } & High & Medium & Low & Nil & \multirow{2}{*}{$\begin{array}{c}\text { Severity of } \\
\text { constraints \% }\end{array}$} \\
\hline & & F/\% & F/\% & F/\% & $\mathrm{F} / \%$ & \\
\hline 1. & $\begin{array}{l}\text { Non availability of } \\
\text { inoculate proper time }\end{array}$ & $\begin{array}{c}5 \\
(4.17)\end{array}$ & $\begin{array}{c}14 \\
(11.67)\end{array}$ & $\begin{array}{c}8 \\
(6.66)\end{array}$ & $\begin{array}{c}93 \\
(77.50)\end{array}$ & 77.22 \\
\hline 2. & Poor quality inoculate & $\begin{array}{c}66 \\
(55.00)\end{array}$ & $\begin{array}{c}34 \\
(28.33)\end{array}$ & $\begin{array}{c}12 \\
(10.00)\end{array}$ & $\begin{array}{c}8 \\
(6.67)\end{array}$ & 78.61 \\
\hline 3. & $\begin{array}{l}\text { Untimely harvesting of } \\
\text { crop }\end{array}$ & $\begin{array}{c}76 \\
(63.33)\end{array}$ & $\begin{array}{c}21 \\
(17.50)\end{array}$ & $\begin{array}{c}13 \\
(10.83)\end{array}$ & $\begin{array}{c}10 \\
(8.34)\end{array}$ & 88.88 \\
\hline 4. & $\begin{array}{l}\text { Unable to use the } \\
\text { instruments }\end{array}$ & $\begin{array}{c}28 \\
(23.33)\end{array}$ & $\begin{array}{c}12 \\
(10.00)\end{array}$ & $\begin{array}{c}5 \\
(4.17)\end{array}$ & $\begin{array}{c}75 \\
(62.50)\end{array}$ & 87.22 \\
\hline 5. & Severe attack of red ants & $\begin{array}{c}97 \\
(80.83)\end{array}$ & $\begin{array}{c}11 \\
(9.16)\end{array}$ & $\begin{array}{c}7 \\
(5.84)\end{array}$ & $\begin{array}{c}5 \\
(4.17)\end{array}$ & 66.11 \\
\hline 6. & Mortality of brood lac & $\begin{array}{c}87 \\
(72.50)\end{array}$ & $\begin{array}{c}22 \\
(18.33)\end{array}$ & $\begin{array}{c}9 \\
(7.50)\end{array}$ & $\begin{array}{c}2 \\
(1.67)\end{array}$ & 15.00 \\
\hline 7. & $\begin{array}{l}\text { Viral infection in brood } \\
\text { lac }\end{array}$ & $\begin{array}{c}58 \\
(48.33)\end{array}$ & $\begin{array}{c}26 \\
(21.67)\end{array}$ & $\begin{array}{c}12 \\
(10.00)\end{array}$ & $\begin{array}{c}24 \\
(20.00)\end{array}$ & 91.11 \\
\hline
\end{tabular}

$\mathrm{F}^{*}=$ Frequency; $\quad \%=$ Percentage 
Table.3 Distribution of the respondents according to institutional constraints faced by the Rangini lac producers

\begin{tabular}{|c|c|c|c|c|c|c|}
\hline \multirow{2}{*}{$\begin{array}{c}\text { S.N } \\
\text { • }\end{array}$} & \multirow[t]{2}{*}{ Constraints } & High & Medium & Low & Nil & \multirow{2}{*}{$\begin{array}{c}\text { Severity } \\
\text { of } \\
\text { constraint } \\
\text { s \% }\end{array}$} \\
\hline & & $\mathrm{F} / \%$ & $\mathbf{F} / \%$ & $\mathrm{~F} / \%$ & F/\% & \\
\hline 1. & Lack of institute for training & $\begin{array}{c}77 \\
(64.17)\end{array}$ & $\begin{array}{c}28 \\
(23.33)\end{array}$ & $\begin{array}{c}14 \\
(11.66)\end{array}$ & $\begin{array}{c}1 \\
(0.83)\end{array}$ & 21.38 \\
\hline 2. & Lack of nearby processing unit & $\begin{array}{c}77 \\
(64.17)\end{array}$ & $\begin{array}{c}24 \\
(16.66)\end{array}$ & $\begin{array}{c}9 \\
(7.50)\end{array}$ & $\begin{array}{c}10 \\
(8.33)\end{array}$ & 32.77 \\
\hline 3. & $\begin{array}{l}\text { Problem of middle man in marketing } \\
\text { channel }\end{array}$ & $\begin{array}{c}97 \\
(80.83)\end{array}$ & $\begin{array}{c}11 \\
(9.17)\end{array}$ & $\begin{array}{c}6 \\
(5.00)\end{array}$ & $\begin{array}{c}6 \\
(5.00)\end{array}$ & 83.61 \\
\hline 4. & $\begin{array}{l}\text { Lack of credit facility for Rangini lac } \\
\text { cultivation }\end{array}$ & $\begin{array}{c}87 \\
(72.50)\end{array}$ & $\begin{array}{c}7 \\
(5.83)\end{array}$ & $\begin{array}{c}5 \\
(4.17)\end{array}$ & $\begin{array}{c}21 \\
(17.50)\end{array}$ & 80.00 \\
\hline 5. & $\begin{array}{l}\text { Lack of crop insurance policy for Rangini } \\
\text { lac production }\end{array}$ & $\begin{array}{c}103 \\
(85.84)\end{array}$ & $\begin{array}{c}11 \\
(9.17)\end{array}$ & $\begin{array}{c}5 \\
(4.16)\end{array}$ & $\begin{array}{c}1 \\
(0.83)\end{array}$ & 88.61 \\
\hline
\end{tabular}

F*=Frequency; $\%=$ Percentage

Table.4 Distribution of the respondents according to other constraints faced by the Rangini lac producers

\begin{tabular}{|c|c|c|c|c|c|c|}
\hline S.N & \multirow[t]{2}{*}{ Constraints } & High & Medium & Low & Nil & \multirow{2}{*}{$\begin{array}{c}\text { Severity of } \\
\text { constraints \% }\end{array}$} \\
\hline • & & F/ \% & $\mathrm{F} / \%$ & $\mathrm{~F} / \%$ & $\mathrm{~F} / \%$ & \\
\hline 1. & $\begin{array}{l}\text { Non availability of labour } \\
\text { at proper time }\end{array}$ & $\begin{array}{c}4 \\
(3.33)\end{array}$ & $\begin{array}{c}9 \\
(7.50)\end{array}$ & $\begin{array}{c}24 \\
(20.00)\end{array}$ & $\begin{array}{c}83 \\
(69.17)\end{array}$ & 77.77 \\
\hline 2. & $\begin{array}{l}\text { Non availability of } \\
\text { instruments for } \\
\text { harvesting }\end{array}$ & $\begin{array}{c}103 \\
(85.83)\end{array}$ & $\begin{array}{c}7 \\
(5.83)\end{array}$ & $\begin{array}{c}5 \\
(4.17)\end{array}$ & $\begin{array}{c}5 \\
(4.17)\end{array}$ & 93.33 \\
\hline
\end{tabular}

Table.5 Suggestions given by Rangini lac producers to overcome the constraints faced by them during adoption of recommended Rangini lac production technology

$(n=120)$

\begin{tabular}{|c|c|c|c|}
\hline S.N. & Suggestions & Frequency & Percentage \\
\hline 1. & Small processing unit should be established by Govt. & 108 & 90.00 \\
\hline 2. & Market facility should be available at nearby place & 55 & 45.83 \\
\hline 3. & Quality seed of lac should be available & 115 & 95.83 \\
\hline 4. & $\begin{array}{l}\text { Insecticides and fungicides should be available at } \\
\text { proper time }\end{array}$ & 38 & 31.66 \\
\hline 5. & $\begin{array}{l}\text { Extension agency should organize training and skill } \\
\text { demonstration about different aspects of lac } \\
\text { production technology at village level }\end{array}$ & 118 & 98.33 \\
\hline 6. & Incentives should be given by Govt. to lac producers & 114 & 95.00 \\
\hline 7. & Insurance of the lac crop should be provided by Govt. & 117 & 97.50 \\
\hline
\end{tabular}

$\mathrm{F}^{*}=$ Frequency; $\quad \%=$ Percentage 
In conclusion, the constraints about recommended production technology practices during of Rangini lac. In case of higher level of constraints, majority of the respondents were reported that they have nor sufficient knowledge regarding suitable plants part for inoculation of lac broods in host tree . In term of adoption of practices in Rangini lac producers have maximum adoption rate in index, the data reveals that adoption of scraping of lac after harvesting or it can better to say that they know nothing about recommended production technology. Bridging the adoption gap in recommended Rangini lac production technology practice in Rangini lac might lead to further increase in the production and productivity of the lac crop in the study area.

\section{Application of research}

Findings of the study will be helpful in designing messages and developing extension strategy for promoting recommended production technology practices on Rangini lac production in the study area

\section{References}

Anonymous Lac, Plant, Resinns and Gums Statistics at a Glance 2014, ICAR- IINR, Ranchi (Jharkhand) India. During the 201718

Kushwaha, D.P. 2005. Study on adoption pattern on rice cultivators Among farmers in northern hill agro climatic zone of C.G.
M.Sc. (Ag) Thesis, IGKV, Raipur.

Shrivastava, R. 2005. Attitude of farmers regarding adoption of control measure practices of various diseases of rice crop in Dhamtari district of Chhattisgarh state. M.Sc. (Ag.) Thesis, IGKV, Raipur (C.G.).

Jayasankar, R. and Thyagarajan, S. 2010. Constraints Experienced by the rice farmers in adopting recommended bio-fertilizer practices. International Journal of Current Research 7:18-20.

Lakra, P.K. 2011. A study on extent of adoption of hybrid rice production technology by the tribal farmers of Surguja district of Chhattisgarh. M.Sc. (Ag.) Thesis, IGKV, Raipur (C.G.).

Kumbhare, N.V. and Singh, K. 2011. Adoption Behaviour and Constraints in Wheat and Paddy Production Technologies. Indian Res. J. Ext. Edu. 11(3): 41-44, September, 2011.

Shori, R., 2011. Attitude of farmers regarding of control mesearement practices of various weeds of rice crop in Dhamatri district of Chhattisgarh state. M.Sc. (Ag.) Thesis, IGKV, Raipur, (C.G.).

Kumari, G. 2012. Constraints in Adoption of Integrated Pest Management (IPM) Practices by Rice Growing Farmers of Jammu Division. Indian Research Journal of Extension Education, Special Issue Vol II, 2012.

Narbaria, S. 2013. A study on adoption level of System of Rice Intensification (SRI) technology among farmers in Dhamtari district of Chhattisgarh. M.Sc. (Ag.) Thesis, IGKV, Raipur (C.G.).

\section{How to cite this article:}

Harishchandra Tanwar, P.K. Pandey and Ashish Kumar Gupta. 2021. An Analysis of Constraints Faced by the Tribes in the Adoption of Recommended Rangini Lac (Kerria Lacca) Production Technology in Chhattisgarh State. Int.J.Curr.Microbiol.App.Sci. 10(01): 13511357. doi: https://doi.org/10.20546/ijcmas.2021.1001.161 